\title{
Production and Destination of Solid Waste in the Chico Mendes Extrative Reserve, Acre, Brazil
}

\author{
Raimundo Cláudio Gomes Maciel ${ }^{1}$, Oleides Francisca de Oliveira1, Jean Marcos da Silva² \\ ${ }^{1}$ Federal Universityof Acre (UFAC), Rio Branco, Brazil \\ ${ }^{2}$ Federal Institute of Education, Science and Technology of Acre (IFAC), Rio Branco, Brazil \\ Email:rcgmaciel@ufac.br, oleides.ufac@gmail.com, suisjean@hotmail.com
}

How to cite this paper: Maciel, R.C.G., de Oliveira, O.F. and da Silva, J.M. (2019) Production and Destination of Solid Waste in the Chico Mendes Extrative Reserve, Acre, Brazil. Journal of Environmental Protection, 10, 791-806.

https://doi.org/10.4236/jep.2019.106047

Received: April 4, 2019

Accepted: June 18, 2019

Published: June 21, 2019

Copyright $\odot 2019$ by author(s) and Scientific Research Publishing Inc. This work is licensed under the Creative Commons Attribution International License (CC BY 4.0).

http://creativecommons.org/licenses/by/4.0/

\begin{abstract}
The process of development of the Amazon, in post-1970, has led to serious socio-economic and environmental problems, such as the struggle for land ownership and huge deforestation. Conservation units, such as extractive reserves (RESEX), appear as sustainable development alternatives for the region. Today, solid waste has become one of the main environmental problems, particularly in forest areas. The aim of the present work is to analyze the production and destination of solid waste in the Chico Mendes RESEX, state of Acre, in the periods 1996/1997, 2005/2006 and 2014/2015. We work with the methodology of the ASPF project, developed at the Federal University of Acre (UFAC), based on indicators of economic results, as well as the production and destination of solid waste. The results indicate a considerable increase in the generation of solid waste in the forest, especially of plastics coming from goods acquired in the market and without adequate disposal.
\end{abstract}

\section{Keywords}

RESEX Chico Mendes, Solid Waste, Amazon Region, Sustainable Development

\section{Introduction}

The amount of litter produced daily affects economic, environmental, and social factors. It is more evident by the consumption of industrialized products by all population, no matter it is urban and/or rural. The production of garbage in forest areas were byproducts of the productive system pertinent to organic mate- 
rials, those of easy decomposition by nature. The term "waste" was supplied by "solid waste". While "garbage" does not add value, the solid waste is reused and transformed into a new product, adding values to the transformed product.

The environmental problems are accentuated by the large-scale production of goods and foodstuffs conditioned by recycled products, also causing greater disposal of packaging that provides the generation of solid waste, which in turn is difficult to degrade to the environment.

In countries dominated by capitalism, consumption is directly linked to the development of society. The industrialized products are the most consumed, those evidenced by the advertising as modern, continuously launched in new models, taking the population to the consumption of many products of difficult deterioration [1].

The people who live in RESEXs are increasingly looking for the "modern" market, with a higher consumption of materials that are not as easily degraded, such as batteries, packaging, batteries and others. They are also unaware of the appropriate forms for disposal of these materials, as well as the collection of these solid wastes [2].

This transition from organic consumption to consumption based on the generation of solid waste that is harmful to forests demands a look at these communities. The concern with the destination of such solid waste is the result of the need to implement public policies concerned with the environment and with sustainable development.

The researches have shown that the studies that explore the production and destination of the solid residues in Acre forests are scarce. The State of Acre occupies a prime position in this context because it is inserted in the Brazilian Amazon, with $75 \%$ of its land covered by forests.

Scientific studies on the production of solid waste in Amazonian forests are relevant, since the presence of these residues can impair the functioning of ecosystems in Amazonian regions. The present study is therefore justified by contributing to discussions that may gap of studies on the subject.

The research is still relevant, as it is part of an emblematic region for the discussion of sustainable development. This study is concerned with the state of Acre, an important federative entity in the process of protection of the Amazonian forest, studying RESEX Chico Mendes.

The general objective of this work is to analyze the production and disposal of solid residues of the families living in the Chico Mendes Extractive Reserve-located in the State of Acre-in the last 20 years, in order to raise awareness of solid waste disposal, which does not harm the environment.

In this perspective it is presented as a research problem to be worked with the following question of investigation: the population that live in the Extractive Reserve Chico Mendes, receive guidance and adequately deal with solid residues inside the forest?

The hypothesis of the present work is that it is not usually thought of the production of solid waste in a significant way to cause environmental damage, 
given the productive activities and the way of life of the families. However, the literature indicates that the amount of rural solid waste has increased significantly over time, given the changing patterns of consumption in rural areas and the greater market dependency of rural households, including within the forest.

\section{Extractive Reserves and Sustainable Development}

The process of occupation of the Amazon, after the 1970s, from the so-called developmentalism, which encouraged the disarticulation of traditional extractivism to the detriment of the "modern" agriculture, led to serious socioeconomic and environmental problems, such as the deforestation of vast areas and the disappearance of populations [3].

These problems have generated immense conflicts in the region, particularly in the struggle for land tenure, with emphasis on the rubber timber social movement, allied to the environmental movement. Thus, public policies as early as the 1980s were pressed for change in the standard development for the emerging concept of sustainable development.

For Sachs [4], sustainable development must be expressed in dimensions and far from being one-dimensional as some literary currents assume by emphasizing care for the "environment" as a synonym for sustainable development, disregarding the cultural, economic, social, and human.

For Cavalcanti et al. [5], the environment is a topic that has attracted the attention of researchers and planners since the 18th century in Europe, with research on flora and fauna, on the cultural and social life forms of peoples. The countries of Europe and the countries of the north began a process of awareness of the destructive power of the human being over natural resources. Convinced that the environment could undergo changes, research and studies on the subject began.

According to Diegues [6], the creation of parks with natural resources preservation purposes originated in the countries of Europe and the United States, however, it is verified that this environmental conception has become the policy of preservation of the natural resources most used by the countries of the Third World.

According to Cavalcanti et al. [4], although the American naturalist conception influenced environmental policies in several Latin American countries, the realities observed in each region are different.

In Brazil there is a very clear example of regional particularities, since the forests are inhabited by indigenous peoples, extractivists and rubber tappers, the so-called traditional populations, who could not be disregarded in the process of elaborating public policies.

In this context, Komiyama \& Takeuchi [7] defend that sustainability emerges as the key issue for contemporary society, conceptualizing it as the need for a balanced development with the environment, guaranteeing social equality for future generations.

In the discussion on sustainable development, it is necessary to have a global 
view of events, which would result in observance of the social, economic, cultural, political, environmental and human dimension [4]. It is not the environmental activists, let alone the classical economists, who must gain prominence in sustainable development, since they are considered contradictory extremes lacking the constant search for the harmonization of economic and environmental objectives [4].

Paulista et al. [8] corroborates with Sachs [4] that the Amazonian forest should be directed to the interests of its inhabitants and of all Brazilians because it represents a potential source of wealth, a stabilizer of the climate and a reserve of the biodiversity.

The guarantee of a healthy lifestyle for present and future generations composes the other variable of sustainable development alongside these dimensions [4]. It is precisely in this scenario that the Conservation Units-UC, are now seen as a strategic possibility to preserve biodiversity. As a result, the coastal areas of humid tropical forest that are inhabited by traditional communities constitute protected natural areas from the 1930s onwards in Brazil [6].

According to Diegues [6], there is a combination of factors that gave rise to this increase in world concern for Conservation Units-PAs: rapid forest devastation, reduced biodiversity and the availability of international financial resources for forest preservation.

The PAs were evidences in Brazil, from the creation of the Forest Code by Law 4.771/1965, with the creation of parks and other conservation units following the naturalistic American environmental logic, whose first intention was the creation of natural public spaces with aesthetics and the production of scientific knowledge [9].

Considering the Brazilian specificities, divide them into two large groups, according to Table 1.

Faced with the pressures of traditional populations such as rubber tappers and extractivists, excluded from the environmental policy of the UH-indirect use (Table 1), UH-direct use begin to intensify, especially in the modalities of Extractive Reserves (RESEX).

RESEXs had as their intention to reduce the land problem of land concentration, to promote the exploitation of natural resources based on sustainable principles and to conserve biodiversity in the Amazonian territory [10].

"The main characteristic of the RESEXs, therefore, is the recovery of the importance of man, in a new perspective of occupation of the Amazonian space, associated to the conservation of the environment where the social, cultural and economic aspects of the local populations are taken into account" [11].

Table 1. Areas for conservationunits.

\begin{tabular}{ll}
\hline \multicolumn{1}{c}{ UC-indirect use } & \multicolumn{1}{c}{ UC-direct use } \\
\hline $\begin{array}{l}\text { Areas of restricted use that do not allow the exploitation of natural } \\
\text { resources, such as parks (national and state) and biological reserves. }\end{array}$ & $\begin{array}{l}\text { Areas that allow human exploration, such as national, state and } \\
\text { municipal forests and environmental protection areas. }\end{array}$ \\
\hline
\end{tabular}

Source: Elaborated from Law 4.771/1965. 
Because it is a policy statement that seeks to protect the natural resources and especially the cultural aspects of a niche of the population and to be located in the forest, the RESEXs are not free of environmental concerns.

According to Maciel et al. [2], in forest regions, waste production has always been related to organic materials, easily decomposed by nature. However, in the present times, forest dwellers, such as RESEX, increasingly depend on the market, with a greater presence of materials that do not have the same degradability. Second Maciel [2] were generated in the years 2006 to 2007 in the forests of Acre about $238,176 \mathrm{~kg}$ of waste.

\section{Solid Waste Production in the Rural Area}

Although the production of solid waste in the rural area is significantly lower than in the urban area, the rural waste, not having a correct final destination, also represents a danger and aggravation to the health of the population to release chemicals that can cause diseases, besides polluting the environment.

For the deliberation of solid waste, preventing and directing the reduction, reuse and recycling, Law No. 12,305/2010 was issued, establishing the National Solid Waste Policy (PNRS).

The collection of solid waste in the rural area is still insufficient/incipient. IBGE-Brazilian Institute of Geography and Statistics reported that in 1991, of the total amount of garbage produced in the rural area, 31.6\% were buried or burned. This percentage rose to $52.5 \%$ in 2000 . The reality is that in RESEXs there is no collection of waste, either solid waste, disposable materials, expired and unusable, which leads extractivists to choose to bury or burn it.

According to Maciel [1], the process of globalization and diffusion of mass consumerism has also reached the rural population, which, increasingly, seeks to adopt patterns of consumption common to the urban environment. A pattern based on the acquisition of "notably mass" consumer goods with programmed obsolescence, and in many cases out of the budget of the rural family.

According to Cavalcanti and Barros [12], electricity has become dominant in rural areas, especially in more recent rural settlements, which are occupied by families who migrated from the countryside and then returned. In this return, the desires of the city go together, including the consumerism of the industrialized products.

Industrialized products will necessarily become solid waste in the rural environment. And this is a problem, since in rural areas there is no garbage collection in most communities.

As a result, most of the waste is improperly disposed of in nature, causing serious problems for the environment:

The uncontrolled increase in consumption results in an increase in the generation of waste, both in quantitative and qualitative terms, in both urban and rural regions. (...) Currently, in addition to the generation of organic waste, there is also the presence of packaging, batteries, etc. [1]. 
At RESEX Chico Mendes, it's no different:

The growing increase in the consumption of products from the "modern" market, by the forest communities of the Amazon, in particular the RESEX Chico Mendes in Acre, has generated a greater accumulation of solid waste. This has caused serious problems for the environment and for the people who depend on it, because the waste, because there is no adequate collection or wrapping, is often played outdoors, that is, inside the forests. The most discarded residues in RESEX are: plastic, metal, glass, stack and paper [2] [5].

Another factor that has also been observed is the lack of basic sanitation services, as well as selective waste collection, which causes the rural population to dispose of waste improperly, either by burning, burying or simply throwing in the bush [13].

Mattoso [14] complements:

In addition to household organic waste, residents of rural areas still deal with waste from activities such as agriculture and animal husbandry. Packaging of agrochemicals, leftovers from crops, machinery scraps and animal waste, for example, require special care. However, the lack of information, sanitation and an efficient collection system lead many farmers to simply discard these materials or to adopt dangerous practices such as burning garbage [14].

Law 12,305/2010, art 47 expressly prohibits the burning and discharge of solid waste in open water or watercourses [15].

It is also highlighted in art. 13 of the aforementioned law the classification of solid waste, categorized them as to the origin and the hazard. Regarding the origin, solid waste can be: household, urban cleaning, urban solid, commercial, sanitation, industrial, health services, civil construction, agrosilvopastoris, transportation services and mining. As for hazardousness, the waste is divided into hazardous and non-hazardous [15].

This behavior is due, in part, to the lack of management policies for this solid waste generated within RESEXs. Recent strategies have pointed out that the disposal of waste should be linked to public policies to avoid inappropriate disposal in the environment, in order to guarantee sustainability within the forests.

\section{Solid Waste Management-GRS}

The concept of solid waste is defined in article 3, item XVI of Federal Law no. $12305 / 2010$, as "material, substance, object or well-disposed result of human activities ... the purpose of which is to proceed, whether to proceed or whether to do so to proceed, in the solid or semisolid states, as well as gases" [15].

In solid waste management the most appropriate designation in the design of the Law should therefore not be "garbage", but "solid waste". Among the objectives of Law No. 12,305/10, the new model proposed by Demajorovic [16] rein- 
forces the objective of "non-generation, reduction, reuse, recycling and treatment of solid wastes as well as an environmentally adequate disposal of tailings" [15].

According to Demajorovic [16] the management of solid waste needs to be concerned with the fate of the material. Figure 1 represents the counterpoint between the "Traditional Model" and the "New Model" of waste treatment.

Reading Figure 1, it can be said that the traditional Model of waste treatment in which the priority is the disposal or disposal of these in a straight line, without any concerns about the destination of the material after the use of them. And the New Model that prioritizes a cycle management, a circular system where a logic prevails in which the quantity of waste to be used are increasing and the quantity to be discarded, smaller [16].

The model presents a notion of circular flow from the stage of the distribution of the product already has a concern with the Recycling. At the consumption stage, recycling remains a priority. In the final disposition the idea of reuse emerges as a concern of the new model. The question of reuse or recycling follows all stages of the process in the new model of Solid Waste Management (GRS).

According to Gouveia [17], the inadequate management of solid waste has the immediate impact on the environment and health, generating climate change. Solid waste management should focus on minimizing the quantities produced by reducing, reusing and recycling.

\section{Methodology}

The present study uses the methodology of the research project entitled "Socioeconomic Analysis of Rural Family Production Systems in the State of Acre-ASPF", developed by the Department of Economics of the Federal University of Acre-UFAC, since 1996, currently captained by the Center of Sciences Juridical and Social Applied (CCJSA).
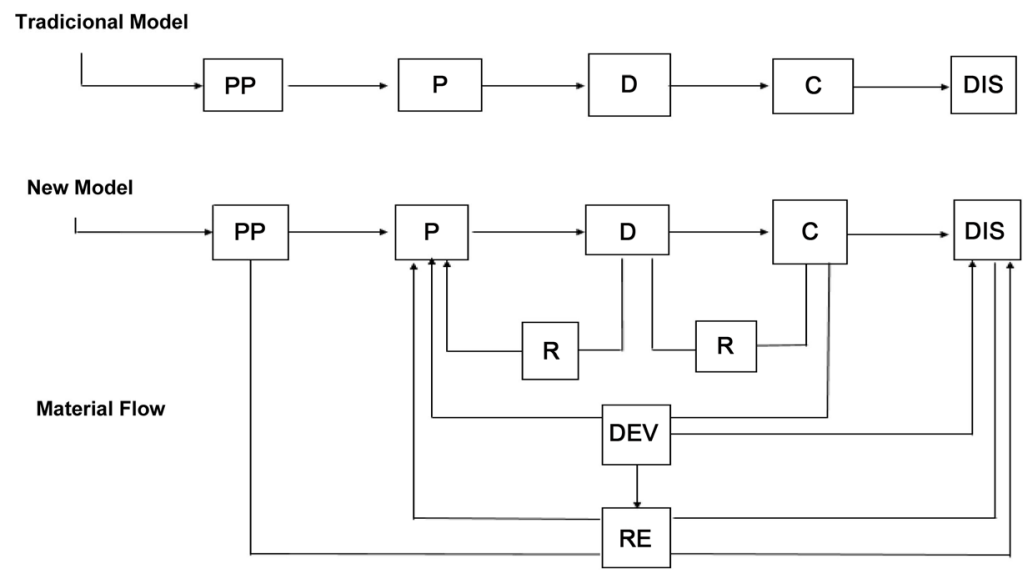

PP - Primary Production; P - Production; D - Distribution; C - Consumption; DIS - Final Disposal; R - Recycling; RE - Reuse; DEV - Return

Figure 1. Solid waste treatment models. Source: Adapted from Demajorovic [16]. 
The object of study of this research is the families settled in the RESEX Chico Mendes, that is located in the State of Acre, covering the following municipalities: Rio Branco, Capixaba, Assis Brasil, Brasileia, Epitaciolândia, Xapuri and Sena Madureira. According to IBAMA [18] the Chico Mendes Extractive Reserve has 970,000 ha, being created in 1990, between the following geographic coordinates: $10^{\circ} 06^{\prime} 11^{\prime \prime}$ a $10^{\circ} 58^{\prime} 39^{\prime \prime}$ south latitude and $67^{\circ} 56^{\prime} 13^{\prime \prime}$ a $69^{\circ} 48^{\prime} 00^{\prime \prime}$ of west longitude. Currently, approximately 2000 families live in the Reserve, structured in 15 Associations, 5 Cooperatives, and 54 Nuclei. Figure 2 shows the location of the RESEX Chico Mendes.

The information was collected by sampling. The sample was defined from three stages:

1) Stratification of the area according to level of development (high, medium or low), with reference to criteria related to production volumes, ease and quality of access, availability of infrastructure and technical assistance, and the degree of community organization.

2) Draw of half of the conglomerates in the study areas-extensions, in the case of agricultural areas, and, in the case of extractive areas, the rubber plantations, in view of the representativeness within each defined stratum.

3) Finally, within each conglomerate drawn, simple random sampling was made, with $10 \%$ of the production units which are part of the study object.

Therefore, from the results obtained it is possible to generalize the data collected for the whole region of study.

In order to gather information, the region's agricultural calendar, defined jointly with the communities studied, was used as reference, referring to the period from May of a given year to April of the following year, encompassing the set of productive economic activities of the families.

In the present research, the information regarding the evolution of the families' performance for the periods of 1996/1997, 2005/2006 and 2014/2015 was used.

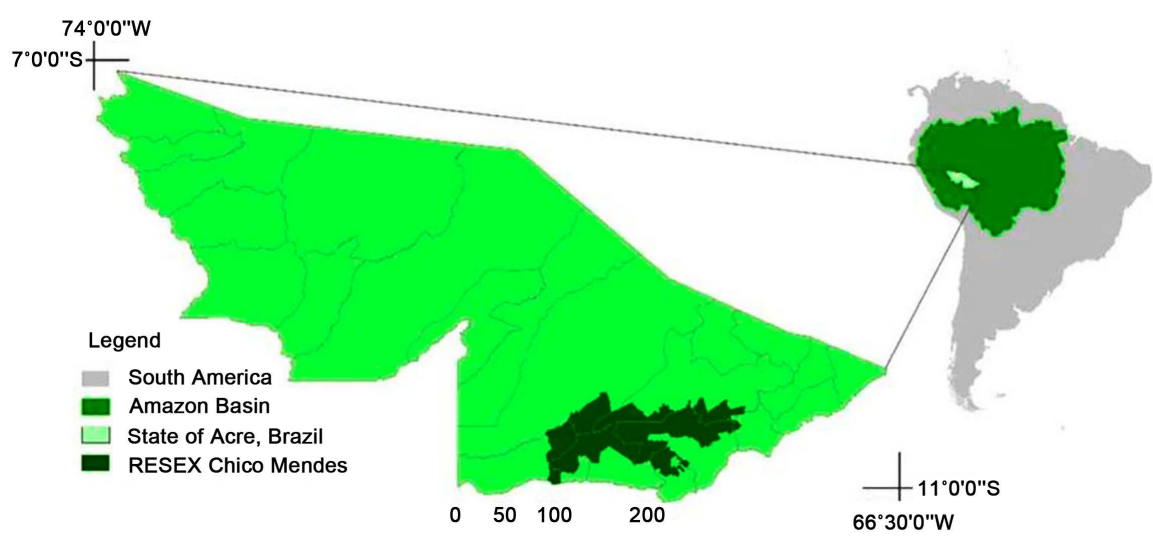

Figure 2. Location of RESEX Chico Mendes, Acre, Brazil. Source: Blog Descalada (adaptado)

https://blogdescalada.com/trilha-chico-mendes-o-trekking-de-90-km-em-reserva-extrativ ista-do-acre/. 
The main economic indicators used are summarized in Table 2, developed by the ASPF [19] project.

The amount of garbage generated in the family production unit is determined by the sum of the weight of the consumer goods purchased on the market and the inputs used in the production, the goods being composed of food, clothing, hygiene and cleaning items, as well as other items products.

Table 3 presents the categories of solid waste used in this work. The verified residues were categorized according to Table 1 , in order to allow an interpretation of the data, with the application of the formulas, having as an indicator, the interviews with the community.

The use of Table 1 made it possible to standardize data analysis and facilitate the interpretation of data by synthesizing the quantity of consumer goods or inputs into categories. The data were collected through interviews with the resident community at the Chico Mendes RESEX in the State of Acre.

Table 2. Economic indicators used in methodology_ASPF [19].

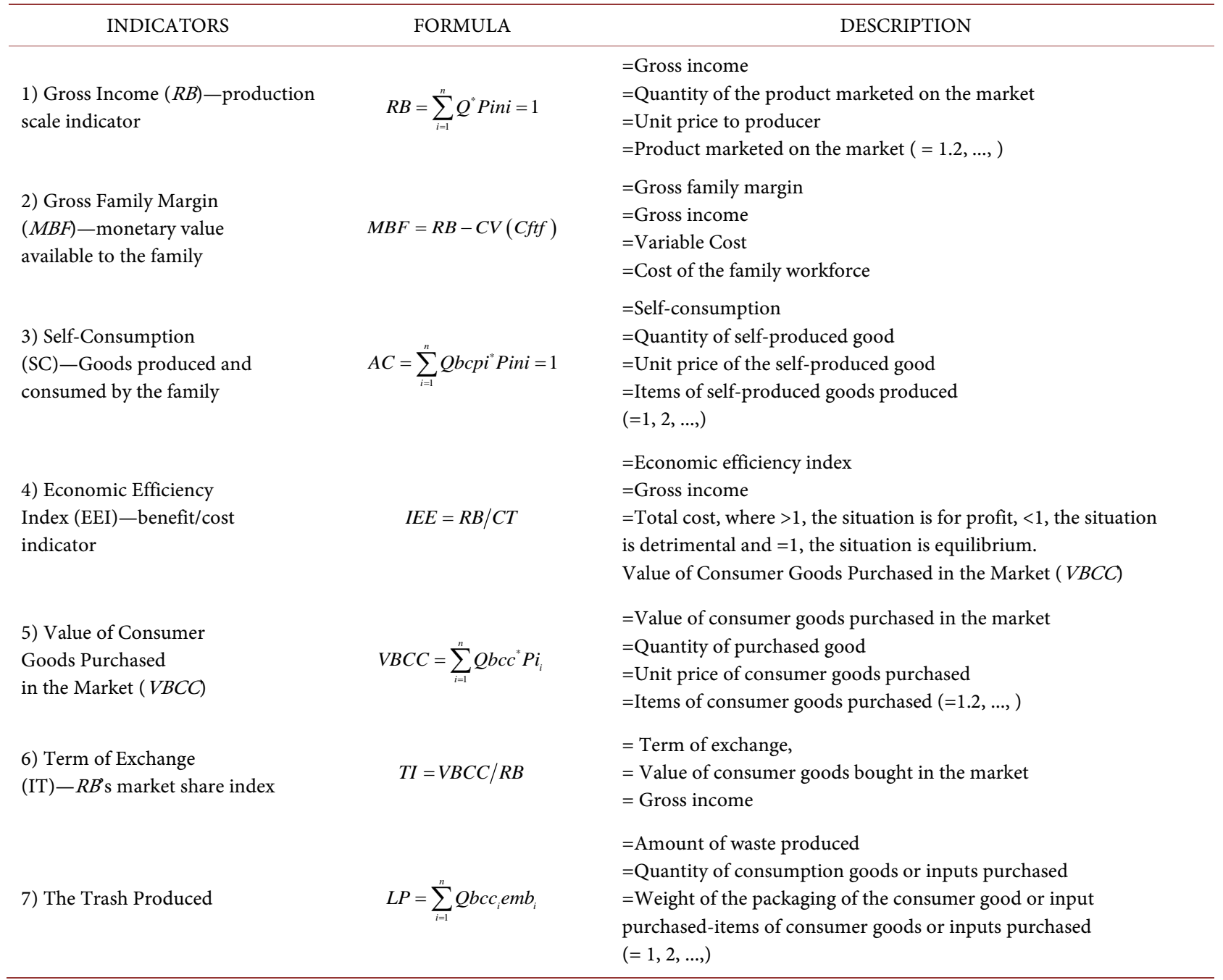

Source: Adapted by the authors from the ASPF methodology ${ }^{1}$.

${ }^{1}$ Available in: https://aspf.wordpress.com/metodologia/. 
Table 3. Definition of solid waste analysis categories in RESEX Chico Mendes.

\begin{tabular}{cl}
\hline Category & Definition \\
\hline Plastic & This category includes bags, bags, styrofoam, plastic toys, packaging, cups, jars. \\
Metal & They are glasses, glass windows, pots of preservatives, bottles. \\
Glass & $\begin{array}{l}\text { They represent materials such as newspapers telephone directories, notebooks, } \\
\text { cardboard boxes, envelopes and printed in general. }\end{array}$ \\
Paper & They include waste not included in the traditional categories, such as tires and dead animals. \\
\hline
\end{tabular}

Source: prepared by the authors (2018).

\section{Results and Discussions}

The generation of solid waste is related to the economic performance of the productive units, the main income indicator is the Gross Family Margin-MBF, being the most appropriate to evaluate the family income, since it is the value pocketed at the end of the productive period for the realization of market expenditures.

According to Table 4, $M B F$ in the medium-year period of 20 years showed an evolution of $14 \%$, which can be considered low compared to the monthly minimum wage (SM) in force in the country, from $\mathrm{R} \$ 954.00$. In fact, all the periods surveyed showed a lower $M B F$ to MS, with a recent period consisting of $48 \%$ of MS. It should also be noted that, at the beginning of the period studied (1996/1997), $M B F$ was more than sufficient for the acquisition of the needs of consumer goods in the market.

With this income, the producer goes to the market to buy the consumer goods, represented in Table 4, by the Value of Goods and Consumption Purchased-VBCC. Therefore, in the recent period the $M B F$ was sufficient only for the acquisition of $64 \%$ of $V B C C$, whose value increased in the last twenty years, impressive $247 \%$, evidencing an increasing dependence on the market.

This $V B C C$ increase can be analyzed by two biases: 1) by the desires of the city, the consumerism of capitalism that enters via television, radio, visits the cities and others; 2) can also be explained by the decrease in self-consumption, which declined by $67 \%$ in the last two decades. On the other hand, it should be noted that at the beginning of the period (1996/1997), self-consumption-AC was $\mathrm{R} \$ 1276.33$, which, together with the $M B F$, generated a living standard in monetary terms of almost $1.8 \mathrm{SM}$ current monthly payments.

The decline in self-consumption over time may be related to low incomes on the one hand and city desires in the "ease" of purchasing ready-to-eat, industrialized consumer goods on the other. However, more accurate research is needed on the subject, since in the market one buys several traditional products of self-consumption, such as rice, beans, meat, flour, vegetables, etc.

The market dependency is also analyzed by the Interchange-IT Term, which shows in the recent period $95 \%$ of the income was for market consumption, with evolution of $143 \%$ in 20 years. Thus, it can be inferred that if $M B F$ is not sufficient 
Table 4. Evolution of the economic performance of the Chico Mendes RESEX-Acre-1996/1997, 2005/2006 and 2014/2015.

\begin{tabular}{|c|c|c|c|c|c|c|c|}
\hline Economic indicators & Unit & $\begin{array}{c}1996 / 1997 \\
\text { (A) }\end{array}$ & $\begin{array}{c}2005 / 2006 \\
\text { (B) }\end{array}$ & $\begin{array}{c}2014 / 2015 \\
\text { (C) }\end{array}$ & $\begin{array}{c}\text { Evolution } \\
(\%) \mathrm{B} / \mathrm{A}\end{array}$ & $\begin{array}{c}\text { Evolution } \\
\text { (\%) } \mathrm{C} / \mathrm{B}\end{array}$ & $\begin{array}{c}\text { Evolution } \\
\text { (\%) } \mathrm{C} / \mathrm{A}\end{array}$ \\
\hline$R B$ & $\mathrm{R} \$ /$ month & 449.25 & 645.80 & 555.52 & $44 \%$ & $-14 \%$ & $24 \%$ \\
\hline GFM & $\mathrm{R} \$ /$ month & 402.79 & 586.77 & 457.55 & $46 \%$ & $-22 \%$ & $14 \%$ \\
\hline$V B C C$ & $\mathrm{R} \$ /$ month & 206.22 & 696.78 & 715.44 & $238 \%$ & $3 \%$ & $247 \%$ \\
\hline$A C$ & $\mathrm{R} \$ /$ month & 1276.33 & 656.91 & 426.21 & $-49 \%$ & $-35 \%$ & $-67 \%$ \\
\hline$I E E$ & und. & 1.37 & 0.74 & 0.67 & $-46 \%$ & $-10 \%$ & $-51 \%$ \\
\hline$T I$ & unt. & 0.39 & 0.63 & 0.95 & $62 \%$ & $50 \%$ & $143 \%$ \\
\hline
\end{tabular}

Note: $R B$-Gross Income; $M B F$-Gross Family Margin; $V B C C$-Consumer Goods Purchased in the Market; AC-Self-consumption; IEE-Economic Efficiency Index; IT-Term of Exchange; Medium values, updated to March 2018 (INPC). Source: ASPF [19].

for the acquisition of consumer goods in the market, the growing dependence on the market may be leading extractivists to indebtedness.

This shows that the increase in solid waste is probably due to a reduction in consumption, which basically generates organic waste, which is easily recycled/reused, and, of course, the increase in the consumption of goods purchased by the $V B C C$.

Figure 3 shows the $V B C C$ by category of goods that were bought in the market: inputs and materials, food, hygiene and cleaning, clothing and others. In this way, it is possible to notice that the category of products "inputs and materials" was the one that presented the greatest growth when compared to the other products, evolving $603.73 \%$, in the two decades analyzed.

Nevertheless, in terms of quantity of purchase, the category of food represents the main expense in the market and, consequently, the largest generator of solid waste in the forest, since the second most representative category, hygiene and cleaning, represents only $30 \%$ of food expenses.

Figure 4 presents the main types of solid waste generated in the region studied, in which plastic stands out with an evolution, in the last 20 years, of $1483 \%$. The results indicate that this expressive evolution is related to the modern packaging used in the purchase of the goods in the market, since the plastic predominates among the types of packaging of the acquired goods.

According to the Information Center on Recycling and EnvironmentRECICLOTECA ${ }^{2}$, plastics generally take more than 500 years to decompose and other wastes, such as metal, hardly even decompose, while the glass does not have a set time for its decomposition.

In quantitative terms, it is worrying the increase of solid waste generation in the forest environment, since in the forests not only the extractive families live, it can be inferred that the amount of waste deposited in the environment is larger and needs more studies than their identification.

${ }^{2}$ Recicloteca is a Recycling and Environmental Information Center created by the NGO Ecomarapendi. More information site access: http://www.recicloteca.org.br/. 


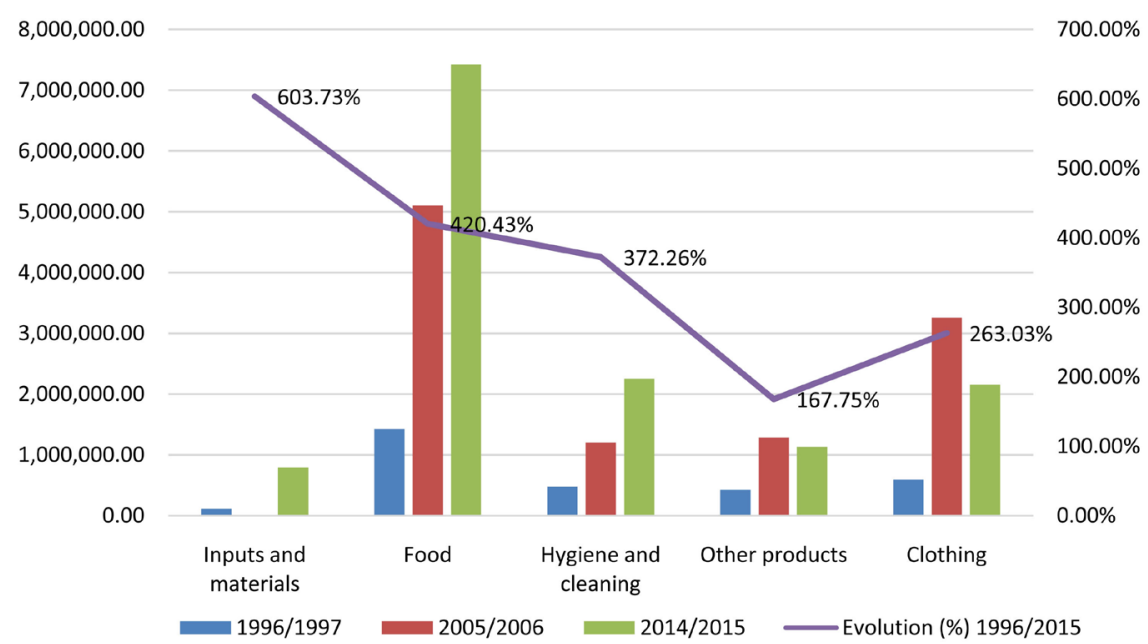

Figure 3. Goods purchased in the market by product category (in R\$), RESEX Chico Mendes, Acre-1996/1997, 2005/2006 and 2014/2015. Source: ASPF [19].

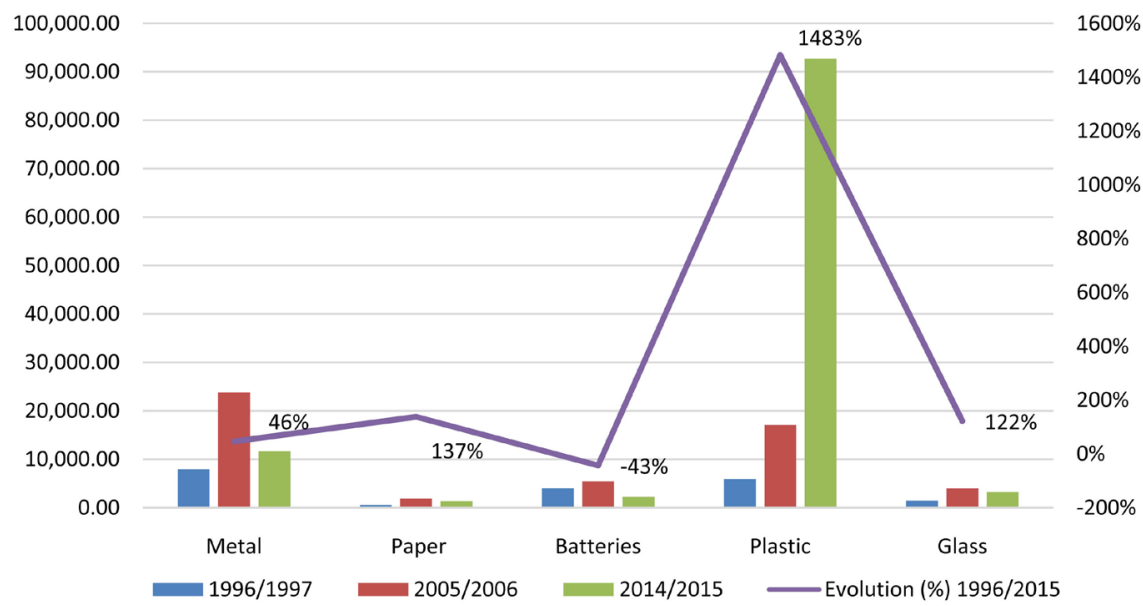

Figure 4. Main types of solid waste (in $\mathrm{kg}$ ) produced in RESEX Chico Mendes, Acre-1996/1997, 2005/2006 and 2014/2015. Source: ASPF [19].

More worrying than the generation of solid waste is the inadequate destination in the forest. According to Figure 5, that, ten years ago, the collection of waste was non-existent in the forest areas, The most commonly used destination, as pointed out in the research, is the "burning", followed by "throw in the woods", discarded in the open (soils and bodies of water) and or is "buried". Thus, solid waste can be causing the pollution of natural resources, since among the improperly discarded waste are batteries, batteries, aerosol containers etc.

It is also worth mentioning the interviews conducted, the lack of orientation for the process of reuse, recycling and reduction of the use of packaging. Many times reuse is done without any criteria and families end up using containers unfit for domestic use.

In the recent period (2014/2015), it can be seen in Figure 6 that practically nothing has changed in the inadequate disposal of the residues generated in the Chico Mendes RESEX, highlighting that the greater quantity of waste from 


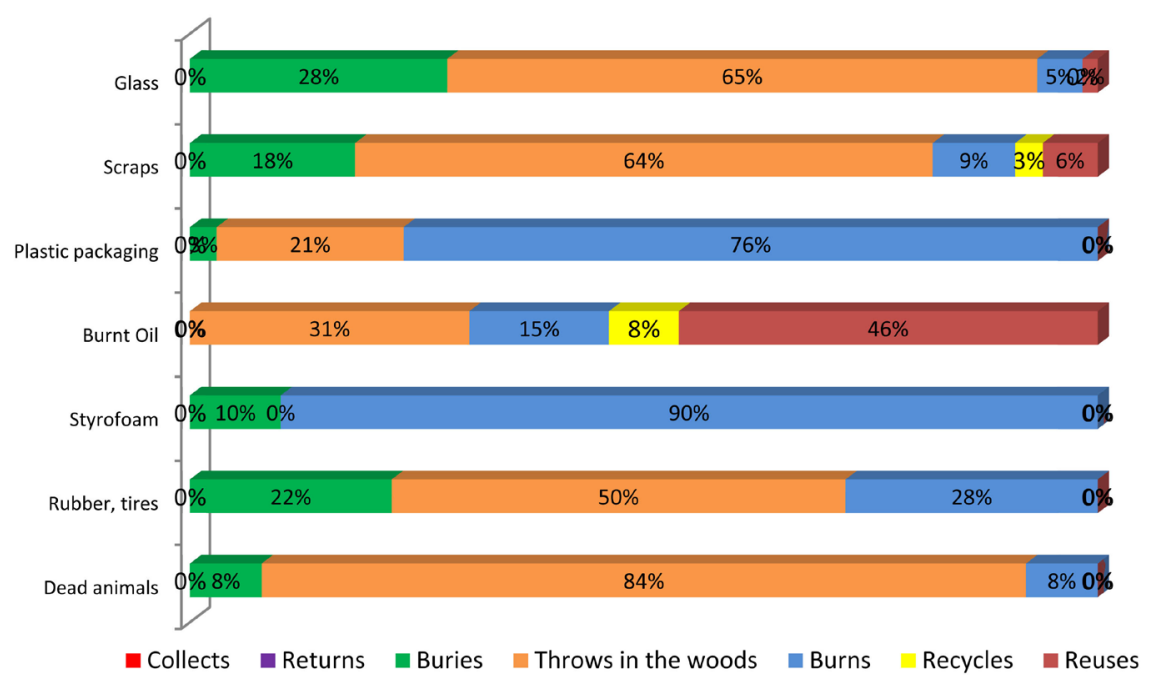

Figure 5. Destinations of solid waste types generated in RESEX Chico Mendes, Acre-2005/2006. Source: ASPF [19].

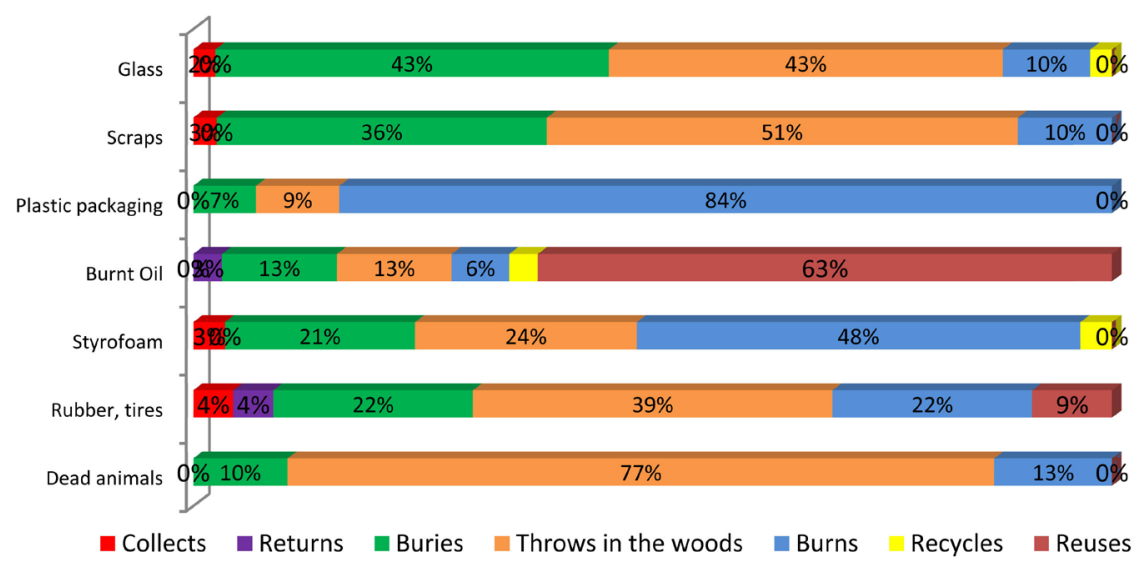

Figure 6. Destinations of solid waste types generated in RESEX Chico Mendes, Acre-2014/2015. Source: ASPF [19].

packaging had a higher destination in the burning of the waste, a form of discard criticized in the literature by Demajorovic [16], for being the model with consequences highly harmful to the environment.

Thus, the disposal of solid waste generated by the families of the Chico Mendes Extractive Reserve, shows that this community has no solid waste management model, remaining with a straight-line treatment, traditional model, unconcerned with the waste destination, especially when observing the "plastic" waste, which is discarded with the burning of the same.

There has been a lack of guidance on the destination of these wastes, which can bring to the environment various types of soil, air and water contamination (polluting rivers, streams and springs), leading to the death of animals, threatening the survival of people in the forest.

The gradual increase of this waste is due to the consumption of industrialized goods, leading the whole population, mainly the small rural producers, to buy 
food instead of producing them and consuming technological products. The surveys carried out in Maciel et al. [1] explain that the reason for this preference is the belief that it does not pay to produce small quantities of food and the desire to obtain products with advanced technology, strongly encouraged by the "modern" market that offers and encourages the acquisition of electronics through advertisements and advertising.

\section{Conclusions}

Industrialized products have brought unregulated consumption to the whole population whether urban or rural. The data analyzed show that small farmers residing in the Chico Mendes RESEX attracted by the offer and varieties of products create a market dependence; they stopped producing their rootstocks from basic products to the natural and artisanal food to search the city, in the modern market that available products are already packaged, mostly in plastic packaging, as well as those of metal and glass, these materials of difficult degradation, known as solid waste.

The residents of RESEX discard without any criterion the solid waste of the products acquired in the market, industrialized, that already come with plastic packaging.

For lack of orientation, it is common to find products of difficult deterioration thrown and or burned to the surroundings of their residences. The burning of solid waste (litter) is the practice most used by RESEX residents, a traditional way of "disappearing" with the waste generated, not knowing that this practice is harmful to health, because it pollutes the air we breathe, damaging the whole environment.

Still in the indicator of solid waste disposal, reaching a high percentage is also the treatment of waste buried and or thrown in the open air, "in the woods", and can have irreparable consequences, by contamination of soil, water and air. It was also verified the destination of containers of pesticides is used in the basic food production processes. However, Law No. 9974 obliges users of pesticides to deliver the used packaging to receiving stations or return it to the dealer, who must pass it on to the manufacturer.

According to Maciel et al. [1] many users unintentionally disregard this law due to the difficulty of access to such receiving posts, or even to the dealer, thus causing inadequate storage.

It is also worth noting the lack of orientation for the process of reuse, recycling and reduction of the use of packaging. Often the reuse is done without any criteria and ends up using improper containers for the domestic use.

Thus, the implementation of awareness-raising projects on the dangers of inadequate disposal of solid wastes, selective waste collection, and the formation of environmental agents with people from the community itself, could contribute to the development of an environmentally sound and supervision by the residents themselves. 
Finally, it is necessary to have more effective public environmental policies to change this scenario and to make use of public policies that already have that treat waste with management and/or by reverse disposition.

\section{Conflicts of Interest}

The authors declare no conflicts of interest regarding the publication of this paper.

\section{References}

[1] Gusmão Junior, V., et al. (2012) A Produção de lixo na floresta: Um novo olhar para as florestas acreanas. Revista de Estudos Sociais, 14, 28. http://periodicoscientificos.ufmt.br/ojs/index.php/res/article/view/1816

[2] Façanha, T.G. and Salgado, Z.L.A.B. (2013) Geração e Destino dos Resíduos Sólidos no Projeto de Desenvolvimento Sustentável Bonal: Por Um Manejo Comunitário e Sustentável. In. X Encontro da ECOECO, Vitória-ES.

[3] Maciel, R.C.G. (2013) Ilhas de Alta Produtividade: Inovação essencial para a manutenção dos seringueiros nas Reservas Extrativistas. IE/UNICAMP, Campinas, 88 p. http://libdigi.unicamp.br/document/?code=vtls000417323

[4] Sachs, I. (1986) Economia e ecologia. VIEIRA, São Paulo.

[5] Cavalcanti, F.C.S., Souza, E.F. and Cavalcante Filho, P.G. (2017) The Emergence of Conservation Units in the Western Amazon: The Case of Extractive Reserves of Acre. In: Annual World Bank Conference on Land and Poverty, Visitedon, Washington DC, $22 \mathrm{p}$.

[6] Diegues, A.C. (2003) O mito moderno da natureza intocada. Hucitec, São Paulo.

[7] Komiyama, H. and Takeuchi, K. (2006) Sustainability Science: Building a New Discipline. Sustainability Science, 1, 1-6. https://doi.org/10.1007/s11625-006-0007-4

[8] Paulista, G., Varvakis, G. and Montibeller-Filho, G. (2008) Espaço Emocional e indicadores de sustentabilidade. Ambiente e Sociedade, Campinas, 11, 185-200. https://doi.org/10.1590/S1414-753X2008000100013

[9] Morsello, C. (2001) Áreas Protegidas Públicas e Privadas: Seleção e manejo. ANABLUME/FAPESP, São Paulo.

[10] Allegretti, M.H. (1989) Reservas Extrativistas: uma proposta de desenvolvimento da floresta amazônica. R. Pará Desenvolvimento, Extrativismo vegetal e reservas extrativistas, Belém, No. 25, 3-29.

[11] CNS Conselho Nacional dos Seringueiros (1993) Diretrizes Para um Programa de Reservas Extrativistas na Amazônia. Poronga, Rio Branco.

[12] Cavalcanti, B.C. and Barros, R.R.deA. (2006) Desejos de Cidade-Imaginários Urbanos em Assentamentos Rurais numa Área de Reserva de Mata Atlântica Brasileira. Horizontes Antropológicos, Porto Alegre, 12, 217-235. https://doi.org/10.1590/S0104-71832006000100011

[13] Pasquali, L. (2012) Composição gravimétrica de resíduos sólidos recicláveis, domiciliares no meio rural de Chopinzinho/PR. http://repositorio.utfpr.edu.br/jspui/bitstream/1/415/1/PB_PPGDR_M_Pasquali\%2 C\%20Luiz_2012.pdf

[14] Mattoso, G. (2013) O que fazer com o lixo rural, 25 de jan.

[15] BRASIL (2010) Lei no 12.305, de 2 de agosto de 2010. Lei da Política Nacional de 
Resíduos Sólidos.

http://www.planalto.gov.br/ccivil_03/_ato2007-2010/2010/lei/112305.htm

[16] Demajorovic, J. (1995) Da política tradicional de tratamento do lixo à política de gestão de resíduos sólidos-As novas prioridades. Revista de Administração de Empresas, São Paulo, 35, 6 p. https://doi.org/10.1590/S0034-75901995000300010

[17] Gouveia, N. (2012) Resíduos sólidos urbanos: Impactos socioambientais e perspectiva de manejo sustentável com inclusão social. Ciência \& Saúde Coletiva, 17, 1503-1510. https://doi.org/10.1590/S1413-81232012000600014

[18] Ibama, Instituto Brasileiro do Meio Ambiente e dos Recursos Naturais Não Renováveis (2006) Diário Oficial da União, Resolução n. 01, de 13 de dezembro de 2006. Plano de Manejo da Reserva Extrativista Chico Mendes, 2006.

https://biblioteca.ibge.gov.br/visualizacao/livros/liv95888.pdf

[19] ASPF Análise Socioeconômica dos Sistemas Básicos de Produção Familiar Rural (2018) Metodologia para análise de Indicadores socioeconômicos. Grupo de pesquisa vinculado ao Centro de Ciências Jurídicas Sociais Aplicadas CCJSA. Fevereiro. 